
ОСОБЛИВОСТІ СТІЙКИХ ВНУТРІШНІХ СТАНІВ ОСОБИСТОСТІ ЖІНОК,
ЩО СПРИЯЮТЬ ВИНИКНЕННЮ ПОЧУТТЯ САМОТНОСТІ

\title{
FEATURES OF SUSTAINABLE INTERNAL STATES OF WOMEN'S PERSONALITY, WHICH CONTRIBUTE TO THE OCCURRENCE OF FEELINGS OF LONELINESS
}

У статті представлені результати дослідження стійких внутрішніх станів особистості жінок, які належать до різних соиіальних груп. Також проведено міжгрупове порівняння, виявлені відмінності цих внуmрішніх станів особистості жінок залежно від приналежності до соціальної групи.

3'ясовано, що стани виражені переважно слабо та помірно, що дозволяє говорити про те, що емоційне ставлення респондентів дещо пригнічене, усвідомлення своїх внутрішніх станів дається їм важко.

У процесі дослідження показано, що жінки, які проживають на тимчасово окупованій території, мають помірно виражений стан безнадії; релігійні жінки - помірно виражені стани «ворожий конфрлікт», «свобода волі» i «безнадія»; у жінок, які перебувають у виправній колонії, вищі майже всі показники внутрішніх станів порівняно з показниками в інших жіночих групах, окрім стану самотності; жінки - переселенки з тимчасово окупованої території мають помірно виражений стан «ворожий консрлікт»; жінки-інваліди - помірно виражені стани «самотність», «ворожий конфрлікт», «свобода волі», «безглуздість існування»; жінки-киянки - помірно виражений стан показників «свобода волі», «безглуздість існування».

Також під час дослідження було виявлено і встановлено статистично значущі відмінності між жіночими групами, де найвищі показники стану самотності були виявлені в жінок, які перебувають у виправній колонії, і жінок-інвалідів; стан «безглуздість існування» значно вище в жінок-киянок, які перебувають у виправній колонії, і жінок-інвалідів порівняно з іншими групами; «свобода вибору, ставлення до авторитету» - статистично значущо більш виражений у жінок, які перебувають у виправній колонії; «статевий консрлікт» - значно вище в жінок, які перебувають у виправній колонії, і жінок-киянок порівняно із представницями інших груп; «ворожий конорлікт» - значущо нижче в жінок, які проживають на тимчасово окупованій території, і жінок-киянок; стан «розбіжності між реальним та ідеальним Я» значущо нижче у групах жінок, які проживають на тимчасово окупованій території, у релігійних та переселенок із тимчасово окупованої території; стан «свобода волі» статистично значущо нижче в жінок, які проживають на тимчасово окупованій території, у жінок - переселенок із тимчасово окупованої території і релігійних жінок; «безнадійність» - значущо більш виражено в релігійних жінок і жінок, які перебувають у виправній колонії, і значущо нижче в жінок-переселенок; показник «почуття неприкаяноcmi, бездомність» значущо вище в жінок, які перебувають у виправній колонії, порівняно із представниками інших груп.

Ключові слова: самотність, соціальні жіночі групи, внутрішні стани, емоційні від- ношення, безнадія, безглуздість існування, ворожий конфрлікт, свобода волі.

The article presents the results of a study of stable internal states of personality of women belonging to different social groups. An intergroup comparison was also made and differences in these internal states of a woman's personality, depending on belonging to a certain social group, were identified.

It was found that mostly, the states are expressed weakly and moderately, which makes it possible to say that the emotional relations of the respondents are somewhat depressed, the realization of their inner states is given to them with difficulty. The study showed that women living in the temporarily occupied territories have a moderate state of "hopelessness"; religious women have a moderate state of "hostile conflict", "freedom of will" and "hopelessness"; women in correctional facilities have almost all internal indicators higher than those in other women's groups, except for loneliness; displaced women from the temporarily occupied territories have a moderate state of "enemy conflict"; women with disabilities moderate moderation of "loneliness", "hostile conflict", "freedom of will", "nonsense of existence"; women from Kiev moderately expressed state of indicators "freedom of will", "nonsense of existence".

The study also identified and established statistically significant differences between women's groups, where: the highest rates of "Ioneliness" were found in women in correctional facilities and women with disabilities; the state of "nonsense of existence" is much higher among women in Kyiv who are in a penal colony and women with disabilities compared to other groups; "Freedom of choice, attitude to authority" is statistically significantly more pronounced in women who are in a penal colony; "Sexual conflict" is much higher among women in a penal colony and women from Kiev compared to representatives of other groups; "Hostile conflict" is significantly lower among women living in the temporarily occupied territory and women from Kyiv; the state of "discrepancy between the real and the ideal self" is significantly lower in the groups of women: living in the temporarily occupied territory, religious and displaced from the temporarily occupied territory; the state of "freedom of will" is statistically significantly lower among respondents who live in the temporarily occupied territory, among women displaced from the temporarily occupied territory, and from religious women; "Hopelessness" is significantly more pronounced in religious women and women who are in a penal colony and significantly lower in displaced women; "Feelings of restlessness, homelessness" are significantly higher in women who are in a penal colony compared to members of other groups. Key words: Ioneliness, social women's groups, internal states, emotional relationships, hopelessness, meaninglessness of existence, hostile conflict, freedom of will. 
Актуальність дослідження підтримується соціальною значущістю жіночої самотності, яка полягає в тому, що досить велика кількість самотніх жінок репродуктивного віку зачіпає інтереси соціуму. А саме в біологічному відтворені й у соціальній структурі цілком (сім'я, робота, виховання тощо). Спираючись на аналіз наукових робот щодо жіночої самотності, можна побачити, що жіноча самотність містить безліч негативних аспектів, які стосуються безпосередньо особистості жінки. Їхні прояви мають широкий діапазон: від психологічної пригніченості до глибокої депресії із суїцидальними намірами, психічними зривами. Отже, у зв'язку з тим, що найчастіше проблеми самотніх жінок зумовлені зміною сформованих стандартів: поведінки, потреб, мотивів, цілей, цінностей, їхньої спрямованості й орієнтацій, які безпосередньо впливають на соціальний статус, то все більш актуальним стає завдання зрозуміти і виявити ті особистісні властивості жінки, які впливають на появу в них почуття самотності.

Сьогодні питанням самотності присвячені праці таких дослідників, як О.О. Мазуренко [3], І.М. Слободчіков [11], які цікавляться проблемами виявлення соціально-філософського осмислення та визначення понять і функцій самотності в умовах, що змінюються в сучасному суспільстві; розглядають проблему самотності в контексті культури (розшарування суспільства, роз'єднаність людей у великих містах, недостатність глибоких емоційних контактів) Ф.Г. Майленова [4], Л.Ф. Новіцька [6], В. І. Молчанов [5]. Праці Ж. В. Пузанової [7; 8] і С.Г. Корчагіної [1] представляють сучасний соціологічний напрям у дослідженні самотності; науковці С.В. Куртіян [2], Л.І. Старовойтова [12] у своїх працях висвітлювали соціальні характеристики самотності; Н.В. Шітова [14] і Н.П. Романова [9], В.І. Сіляєва [10] у своїх роботах приділяли увагу соціально-психологічним особливостям самотніх жінок, їхньому статусу в соціумі, образу Я. А ось А.Ф. Фаррахов [13] у своїх дослідженнях вивчав соціальні чинники, які сприяють появі почуття самотності в молоді. Закордонні автори висвітлювали проблеми соціальної й емоційної самотності розлучених і одружених чоловіків та жінок (P.A. Dykstra, T. Fokkema) [16]. Етіологію індивідуальних відмінностей у почутті самотності вивчали M.A. Distel, I. RebolloMesa, A. Abdellaoui, C.A. Derom, G. Willemsen, J.T. Cacioppo, D.I. Boomsma [15], водночас приділяли особливу увагу соціальній ізоляції та самотності людей, пов'язаних із фізичною та психологічною захворюваністю, а також зі смертністю.

Метою дослідження є виявлення стійких внутрішніх станів жінок із різних соціальних груп, які впливають на появу почуття самотності.
Дослідження жіночої самотності нерозривно пов'язане з аналізом індивідуально-особистісних стійких внутрішніх станів людини, які впливають на рівень формування самотності в жінок, які перебувають у різних соціальних групах. Тому для розуміння найбільш характерних особливостей стійких внутрішніх станів, особистості самотньої жінки, зважаючи на її приналежність до визначеної групи, ми виявили середні значення показників, які пов'язані з переживанням почуття самотності.

Зазначимо, що в нашому дослідженні середні значення представлені «медіаною» (середнє значення для вибірки) у таблицях і графіках кожної соціальної групи жінок окремо. Першим кроком статистичної обробки даних була перевірка даних на нормальність. Для цього ми використали критерій Колмогорова - Смірнова (One-Sample Kolmogorov Smirnov Test) до шкал усіх методик, за якими проводили дослідження. Спираючись на узагальнювальний показник Asymp. Sig. (2-tailed), який нижче 0,05 за кожним із показників, ми можемо стверджувати, що розподіл даних ненормальний. Отже, для подальшого оброблення даних застосований непараметричний метод обробки даних, а саме непараметричний критерій Манна - Уітні, окрім t-критерію Стьюдента для виявлення статистично значущих відмінностей показників між шістьма групами респондентів. Це дало можливість побачити рівень вираженості (із дотриманням норм у методиках) того чи того показника в кожній досліджуваній групі жінок окремо. А також отримати переважно статистично значущі відмінності в показниках між усіма групами загалом, якщо такі $\epsilon$.

У процесі аналізу одержаних результатів за методикою «Особистісного опитувальника емоційного ставлення» А.Т. Джерсайлда, який спрямований на визначення стійких внутрішніх станів особистості жінок із різних соціальних груп, що впливають на їхнє ставлення до навколишнього середовища, були отримані середні значення (медіана), які представлені в таблиці 1.

У результаті проведеного аналізу отриманих показників досліджуваних шістьох жіночих груп (табл. 1) за «Особистісним опитувальником емоційного ставлення» А.Т. Джерсайлда відзначимо, що стани виражені переважно слабо та помірно, що дозволяє говорити про те, що емоційне ставлення респондентів дещо пригнічено, усвідомлення своїх внутрішніх станів дається їм важко. Проаналізуємо кожну групу окремо.

Група 1. Жінки, які проживають на тимчасово окупованій території, мають низькі показники всіх внутрішніх станів, крім «безнадія», який помірно виражений. Це свідчить про те, що іноді вони відчувають песимістичні стани 
Порівняння середніх показників стійких внутрішніх станів особистості жінок із різних соціальних груп за "Особистісним опитувальником емоційного ставлення" А.Т. Джерсайлда

\begin{tabular}{|c|c|c|c|c|c|c|c|c|c|}
\hline Медіана & 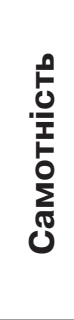 & 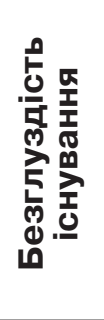 & 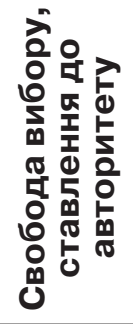 & 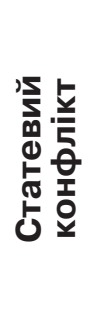 & 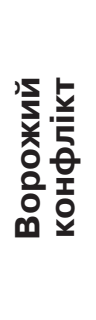 & 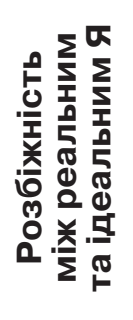 & 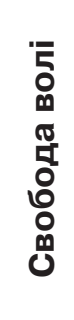 & 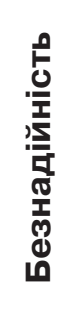 & 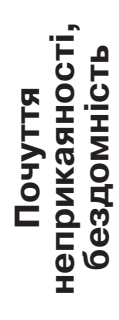 \\
\hline $\begin{array}{c}\text { Жінки, які проживають } \\
\text { на тимчасово окупованій } \\
\text { території }\end{array}$ & 0 & 1 & 1 & 0 & 1 & 1 & 1 & 3 & 0 \\
\hline Релігійні жінки & 1 & 2 & 2 & 1 & 4 & 0 & 3 & 4 & 0 \\
\hline $\begin{array}{c}\text { Жінки, які перебувають } \\
\text { у виправній колонії (далі - ВК) }\end{array}$ & 2,5 & 3 & 3 & 3 & 4 & 3 & 3,5 & 3 & 3 \\
\hline $\begin{array}{c}\text { Жінки - переселенки з } \\
\text { тимчасово окупованої } \\
\text { території }\end{array}$ & 0,5 & 1,5 & 2 & 0 & 3 & 0,5 & 2 & 1,5 & 0 \\
\hline Жінки-інваліди (глухонімі) & 3 & 3 & 2 & 1 & 4 & 2,5 & 4 & 2 & 1 \\
\hline Жінки-киянки & 1 & 3 & 1 & 2 & 2 & 2 & 4 & 2 & 1 \\
\hline
\end{tabular}

щодо майбутніх перспектив і власного Я, своєї значущості. Їм властиве почуття втрати важливих можливостей і неможливості надолужити згаяне, а також сумніви в необхідності продовжувати боротьбу для досягнення життєво важливих цілей, що сприяє появі почуття незадоволеності від докладених зусиль у роботі, навчанні, сімейних справах. Вони також мають низький рівень тенденції до почуття обмеженості своїх можливостей робити власний вибір за будь-яких обставин. Усе це більшою мірою зумовлено подіями, які розгорнулися на території Донбасу.

Група 2. Релігійні жінки мають помірно виражений стан за показниками «ворожий конфлікт», “Свобода волі» і «безнадія», усі інші показники мають слабо виражений стан. Це свідчить про те, що ця група має тенденції намагатися обстоювати свою межі, робити власний вибір майбутніх перспектив, але водночас від свого внутрішнього стану почуття недостатньої значущості (на роботі, у сім'ї) жінки втрачають самовладання або відчувають почуття обурення, гніву в ситуаціях, коли на їхню особистість чинять тиск, підганяють, нав'язують свою думку, особливо якщо немає можливості чинити опір цьому або проявляти своє невдоволення. Водночас вони можуть відчувати втрату можливостей у минулому житті, неможливість надолужити згаяне.

Група 3. Жінки, які перебувають у виправній колонії, серед шести жіночих груп мають більшу частину показників станів, які помірно виражені, а саме: «безглуздість існування», «свобода вибору, ставлення до авторитету»,
«Статевий конфлікт», «ворожій конфлікт», «розбіжність між реальним і ідеальним Я», «свобода волі», «безнадія», «почуття неприкаяності, бездомність». Слабо виражений тільки показник «самотність». Також варто зазначити, що практично всі показники внутрішніх станів цієї групи вище за показники в інших жіночих групах.

Отже, у результаті проведеного аналізу отриманих даних можемо зазначити, що жінкам цієї групи властива тенденція до почуття обмеженості у своєму виборі бажань і потреб. Вони мають схильність відчувати труднощі бути самим собою в навколишньому середовищі, захистити себе, обстоювати своє право на власні бажання і думки, а також користуватися правом протестувати проти насилля і статевого конфлікту. У ті моменти, коли на них чинять тиск, їх підганяють, нав'язують власну думку, вони відчувають свою малу значущість, втрачають самовладання, відчувають стан обурення і гніву. Також ця група жінок відчувають себе відчуженими, що зумовлено їнім недостатнім спілкуванням і обмеженістю в контактах з оточенням, сім'єю та рідними. Але вони не втрачають надії на перспективи в майбутньому.

Група 4. У жінок - переселенок із тимчасово окупованої території слабо виражені всі показники внутрішніх станів, окрім «ворожий конфлікт», який помірно виражений. Отже, ми можемо говорити про те, що ці жінки досить включені в соціум, у спілкування з оточенням, сімейні відносини, роботу, тобто мають почуття включення в навколишні події. Але водночас вони відчувають свою малу 
значущість у важливих подіях власного життя, що безпосередньо впливає на їхню незадоволеність від докладених зусиль щодо роботи і сім'ї. Також їм притаманне відчуття обмеженості своїх можливостей робити вільний вибір бажань і потреб незалежно від обставин. Іноді ці жінки відчувають деякі труднощі в тому, щоб бути самим собою у відносинах з оточенням, особливо з тими, у кого вище становще або ранг, та, у разі необхідності, захистити себе, обстоювати право на власні бажання і думки.

Група 5. У жінок-інвалідів помірно виражені внутрішні стани «самотність», «безглуздість існування», «ворожий конфлікт», «свобода волі», усі інші показники слабо виражені. У результаті проведеного аналізу отриманих показників можна говорити про те, що жінкам-інвалідам притаманне переживання помірної ізольованості, нерозуміння іншими. Відчувається незадоволена потреба у спілкуванні і близьких відносинах. Наявні труднощі у встановленні нових контактів, подружніх зв'язків. Легке відчуття малої значущості та важливості подій, які відбуваються в житті особистості жінки-інваліда, зумовлює незадоволеність отриманого результату в роботі, навчанні та сім'ї. У ситуаціях, де на них чинять тиск або нав'язують їм свою думку, вони можуть втрачати самовладання, відчувати стан обурення і гніву. Їхня інвалідність не стає перешкодою для того, щоб вважати себе людиною з обмеженнями, яка потребує допомоги у вирішенні власних життєвих проблем.

Група 6. Жінки-киянки мають помірно виражені показники «безглуздість існування» і «свобода волі», усі інші показники мають слабо виражений стан. Це свідчить про те, що жінки-киянки не відчувають обмежень у спілкуванні і близьких відносинах. Вони не мають труднощів у встановлені нових контактів і подружніх зв'язків. Не ставлять для себе обмежень у можливостях робити вибір незалежно від обставин. Для них усе, що відбувається у власному житті, має значущість і важливість, тому докладені зусилля в роботі та сімейних стосунках приносять задоволення. Свої життєві проблеми вони намагаються вирішити власноруч, водночас не мають сумніву в необхідності продовжувати боротьбу за досягнення життєво важливих цілей.

Далі за методом попарного порівняння Мана - Уітні було визначено статистично значущі відмінності стійких внутрішніх станів особистості жінок із різних соціальних груп, які представлені в таблиці 2.

Якщо говорити про статистично значущі відмінностей результатів методики між групами, то ми можемо виділити такі ключові моменти:

Стан самотності значущо вище в жінок, які перебувають у виправній колонії, і в жінок-ін- валідів (глухонімі), порівняно із представниками інших груп. Це означає, що переважно саме цим жіночим групам більше властиве переживання негативних емоцій ізольованості від інших, покинутості та нерозуміння оточенням. Саме в цих групах спостерігаються труднощі у встановлені нових контактів і подружніх зв'язків, що відображається на обмеженні спілкування та формування близьких стосунків. Ми вважаємо, що саме об'єктивні чинники, як-от вимушена соціальна ізоляція жінок, які перебувають у виправній колонії, і особливості здоров'я (проблема слуху), безпосередньо впливають на відчуття соціальної ізоляції від інших і переживання суб'єктивної самотності.

Стан безглуздості існування значно розрізняється у респонденток, а саме в жінок-киянок, жінок, які перебувають у виправній колонії, і жінок-інвалідів порівняно 3 іншими групами. Це свідчить про те, що для них всі події, які відбуваються в їхньому житті, набувають значущості.

У жінок, які перебувають у виправній колонії, статистично значущий та більш виражений показник «свобода вибору, ставлення до авторитету» порівняно із представниками інших груп. Це говорить про те, що їм притаманна тенденція до почуття обмеження власного вибору стосовно своїх бажань та потреб. Вони мають труднощі щодо власного вибору бути самими собою в соціальному оточені, особливо з тими, хто має більший авторитет чи ранг. Також їм притаманні труднощі в самозахисті, у можливості мати власну думку, мати право протесту проти насилля. Усе це зумовлено соціально закритою структурою виправної колонії.

Статевий конфлікт значущо вищий у жінок, які перебувають у виправній колонії, порівняно із представницями інших груп. Потім вищу статистичну значущість значення за показником «статевий конфлікт» має група жінок-киянок. У релігійних жінок і жінок-інвалідів показник виражений значущо вище, ніж у групах жінок, які проживають на тимчасово окупованій території, і жінок - переселенок із тимчасово окупованої території. Отже, можна говорити про те, що переживання реальної або уявної невідповідності своєї статево-рольової поведінки референтним статево-рольовим зразкам найбільше притаманне жінкам, які перебувають у виправній колонії. Де вони найбільше стикаються із труднощами реалізації власної статевою ролі у взаєминах з оточенням, що в соціумі відображає ступень особистої зрілості і соціальної адаптованості. Водночас їхня несформованість та дисгармонійність статево-рольової поведінки можуть зумовлювати як внутрішній психологічний конфлікт, який має супровід стресу, так і зовнішній конфлікт відносин з оточенням. 


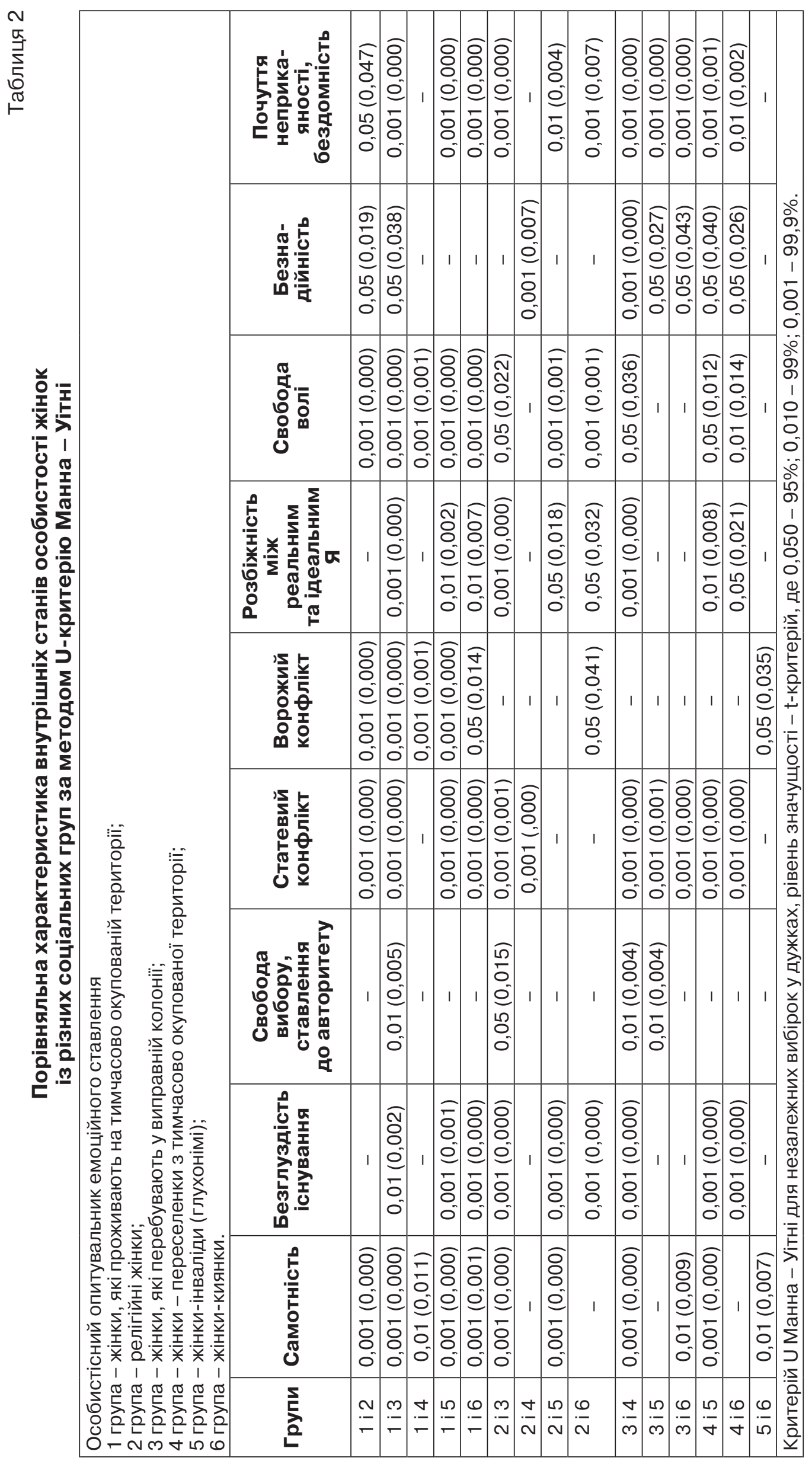


Ворожий конфлікт значущо нижче в жінок, які проживають на тимчасово окупованій території, порівняно з іншими групами. Також цей показник значущо нижче в жінок-киянок порівняно $з$ релігійними жінками і жінками-інвалідами. Це свідчить про те, що жіночим групам: релігійним-жінкам, жінкам-інвалідам, жінкам - переселенкам із тимчасово окупованої території і жінкам, які перебувають у виправній колонії, властиво втрачати самовладання або відчувати почуття обурення, гніву, люті в ситуаціях, коли на їхню особистість чинять тиск або їх підганяють, нав'язують їм свою думку, особливо якщо немає можливості чинити опір цьому або проявляти своє невдоволення.

Показник розбіжності між реальним та ідеальним Я значущо нижче у групах жінок, які проживають на тимчасово окупованій території, релігійних і переселенок із тимчасово окупованої території, ніж в інших групах. Це говорить про те, що жінкам, які перебувають у виправній колонії, інвалідам і жінкам-киянкам притаманно відчуття незадоволеності сприйняття самої себе такою, яка $€$, своїми соціальними ролями та набором власних рис. Водночас у взаємодії з навколишнім середовищем їхні розбіжності між «Я реальним» і «Я ідеальним» можуть призводити до спотвореного сприйняття реальності, унаслідок чого формуються конструкти самооцінки і самоефективності. Утворена внутрішньоособистісна неузгодженість у цих групах має два напрями розвитку залежно від рівня розбіжності Я-концепції особистості. Якщо в жінок, які перебувають у виправній колонії, найбільший рівень розбіжності, то це свідчить про те, що вони відчувають дисонанс, який супроводжується внутрішнім конфліктом, має амбівалентні прояви, як-от: депресія, підвищене самолюбство, нездорова амбітність, зарозумілість, що зумовлюється недосяжністю ідеалу. У жінок-інвалідів показники розбіжності трішки нижче, ніж у жінок, які перебувають у ВК, але вище порівняно з іншими групами, це говорить про те, що вони докладають максимум зусиль і старанності, щоб відповідати очікуваним результатам. У жінок-киянок також спостерігається підвищений рівень розбіжності, але він виступає двигуном особистісного розвитку.

Свобода волі статистично значущо нижче в жінок, які проживають на тимчасово окупованій території, порівняно з іншими жіночими групами, але він також значущо нижче в жінокпереселенок із тимчасово окупованої території і релігійних жінок порівняно з жінками-киянками, жінками-інвалідами і жінками, які перебувають у виправній колонії. Отже, можна говорити про те, що жінкам, які проживають на тимчасово окупованій території, і переселенкам, а також релігійним жінкам властиво почуття обмеженості власних можливостей робити вибір незалежно від обставин. У них наявна схильність бачити себе людиною, яка потребує, шукає і приймає допомогу з боку інших людей у вирішуванні власних життєвих проблем.

Стан безнадійності значущо більш виражений у релігійних жінок і жінок, які перебувають у виправній колонії, порівняно із групами жінок-киянок, жінок - переселенок із тимчасово окупованої території, жінок-інвалідів. До того ж цей показник статистично значущо нижче в жінок-переселенок порівняно з іншими групами і статистично значущо вище в жінок-інвалідів порівняно із групою жінок переселенок із тимчасово окупованої території. Отже, можна говорити про те, що саме жінкам-інвалідам і жінкам, які перебувають у ВК, властиве песимістичне сприйняття реальності, власного «я» і майбутніх перспектив у негативно забарвлених тонах. У них спостерігається відчуття втрати важливих можливостей у минулому житті, неможливості надолужити згаяне. Вони мають сумніви щодо необхідності продовжувати боротьбу за досягнення життєво важливих цілей.

Почуття неприкаяності, бездомність значущо вище представлені в жінок, які перебувають у виправній колонії, порівняно із представниками інших груп. Додатково цей показник значущо більш виражений у жінок-киянок і жінок-інвалідів порівняно із жінками, які проживають на тимчасово окупованій території, релігійними жінками та жінками - переселенками з тимчасово окупованої території, але за середніми показниками перебуває на низькому рівні. Це свідчить про те, що саме жінкам, які перебувають у виправній колонії, властиве переживання «бездомності» у фізичному і психологічному сенсі цього слова. Наявне почуття відчуженості від подій, які відбуваються навколо них. Мала особистісна включеність у роботу, спілкування з оточенням, сімейні відносини.

Отже, у процесі дослідження виявлено, що внутрішні стани особистості жінок у шістьох групах переважно виражені слабо та помірно. Але це дає нам можливість говорити про те, що особистісне емоційне ставлення жінок-респонденток пригнічено, усвідомлення своїх переживань дається їм важко, що на рівні тенденції може бути захисною реакцією.

Виявлено, що жінки, які проживають на тимчасово окупованій території, мають помірно виражений стан «безнадія», це вказує на те, що таким жінкам властиве переживання почуття обмеженості своїх можливостей робити власний вибір за будь-яких обставин. Почуття втрати важливих можливостей і неможливість надолужити згаяне, мають песимістичний окрас щодо майбутніх перспектив 
і розвитку власного Я за набуття певної значущості в соціумі. На нашу думку, це більшою мірою зумовлено подіями, які розгорнулися на території Донбасу.

З'ясовано, що в релігійних жінок помірно виражені стани «ворожий конфлікт», «Свобода волі» і «безнадія», що вказує на те, що їм властиво втрачати самовладання в ситуаціях, коли на їхню особистість чинять тиск, підганяють, нав'язують свою думку, особливо якщо немає можливості чинити опір цьому або проявляти своє невдоволення, щодо обстоювання власних меж, власного вибору на майбутне. Водночас вони можуть відчувати втрату можливостей у минулому житті, неможливість надолужити згаяне.

За результатами дослідження визначено, що у групи жінок, які перебувають у виправній колонії, практично всі показники внутрішніх станів вище за показники в інших жіночих групах. Це свідчить про те, що ця жіноча група відчуває передусім свою відчуженість, що зумовлено обмеженням спілкування, у контактах із навколишнім середовищем, сім'єю та рідними. Відчувають свою обмеженість у власному виборі бажань і потреб, мають труднощі в тому, щоб залишатися собою, захисти себе, обстояти право на власні бажання і думки, а також користуватися правом протестувати проти насилля і статевого конфлікту. Коли на них чинять тиск, принижують їхню значущість, їм властиво втрачати самовладання, проявляти агресію. Але вони не втрачають надії на перспективи в майбутнім.

Виявлено, що жінкам - переселенкам із тимчасово окупованої території властиве переживання «ворожий конфлікт», що вказує на те, що ці жінки досить включені в соціум (робота, сім'я), у події, які відбуваються навколо них. Але вони не відчувають повної задоволеності від цього, що зумовлено обмеженістю робити власний вільний вибір, щодо бажань і потреб незалежно від обставин. Іноді вони відчувають деякі труднощі в тому, щоб розкритися і бути собою у взаєминах з оточенням, особливо з тими, хто має вище становище або ранг. Також наявні труднощі в разі необхідності захистити себе, обстояти право на власні бажання і думки, що впливає на їхнє почуття незадоволеності.

У результаті проведеного аналізу показників жінок-інвалідів можна стверджувати, що їм притаманне переживання помірної ізольованості, що зумовлено станом здоров'я, непорозумінням з оточенням, з агресивними проявами в ситуаціях, коли на них чинять тиск, нав'язують їм іншу думку, незадоволеною потребою у спілкуванні і близьких стосунках, труднощами у встановленні нових контактів і подружніх зв'язків. Відчуття малої значущості та важливості подій, які відбуваються в житті особистості жінки-інваліда, впливають на відчуття незадоволеності власним життям. Але їхня інвалідність не стає перешкодою для того, щоб вважати себе людиною з обмеженнями, яка потребує допомоги у вирішенні власних життєвих проблем.

Установлено, що жінки-киянки, навпаки, не мають труднощів у спілкуванні, установлені нових контактів, у близьких стосунках. Вони не ставлять для себе обмеження у вільному виборі, для них все, що відбувається у власному житті, має певну значущість і важливість, тому докладені зусилля в роботі та сімейних відносинах приносять задоволення. Свої життєві проблеми вони намагаються вирішити власноруч, водночас не мають сумніву в необхідності продовжувати боротьбу за досягнення життєво важливих цілей.

Під час дослідження було виявлено і встановлено статистично значущі відмінності між жіночими групами, а саме: найвищі показники стану «самотність» були виявлені у жінок, які перебувають у виправній колонії, і жінок-інвалідів, що зумовлено передусім об'єктивними чинниками: соціальною ізоляцією і станом здоров'я (глухота). Стан «безглуздість існування" значно вище в жінок-киянок, жінок, які перебувають у виправній колонії, і жінок-інвалідів порівняно з іншими групами, що свідчить про те, що для них всі події їхнього життя набувають певної значущості. Статистично значущо більш виражений показник «свобода вибору, ставлення до авторитету" у жінок, які перебувають у ВК, порівняно із представниками інших груп, що зумовлено соціально закритою структурою виправної колонії. Стан «статевий конфлікт" значно вище в жінок, які перебувають у ВК, і жінок-киянок, ніж у представниць інших груп. У релігійних жінок і жінок-інвалідів показник виражений значущо вище, ніж у групах жінок, які проживають на тимчасово окупованій території, і жінок - переселенок із тимчасово окупованої території. Отже, можна говорити про те, що переживання реальної або уявної невідповідності своєї статево-рольової поведінки референтним статево-рольовим зразкам найбільше притаманне жінкам, які перебувають у виправній колонії. Стан «ворожий конфлікт» значущо нижче в жінок, які проживають на тимчасово окупованій території, і жінок-киянок, ніж у респонденток з інших груп, що свідчить про те, що цим жіночим групам більш властиво встановлювати власні межі з оточенням, обстоювати власну думку, контролювати свої емоційні стани і поведінку. Стан «розбіжності між реальним та ідеальним Я» значущо нижче у групах жінок, які проживають на тимчасово окупованій території, релігійних та переселенок із тимчасово окупованої території, ніж в інших групах, що свідчить про мінімальну розбіжність у Я-концепції особистості 
в цих групах. Стан “свобода волі" статистично значущо нижче в жінок, які проживають на тимчасово окупованій території, у жінок переселенок із тимчасово окупованої території та релігійних жінок у порівнянні з іншими жіночими групами. Це вказує на те, що в цих жіночих групах спостерігається більше почуття обмеженості власних можливостей робити вибір незалежно від обставин. Стан «безнадійність" значущо більш виражений у релігійних жінок і жінок, які перебувають у ВК, і значущо нижче в жінок - переселенок порівняно з іншими групами. Також статистично значущо вище в жінок-інвалідів, ніж у жінок - переселенок із тимчасово окупованої території. Стан “почуття неприкаяності, бездомність» значущо вище в жінок, які перебувають у ВК, порівняно із представниками інших груп. Це говорить про те, що саме їм властиве переживання бездомності у фізичному і психологічному сенсі цього слова.

\section{ЛІТЕРАТУРА:}

1. Корчагина С.Г. Психология одиночества : учебное пособие. Москва : Московский психолого-социальный ин-т, 2008. 228 с.

2. Куртиян С.В. Одиночество как социальное явление : автореф. дис. ... канд. соц. наук: 22.00.04. Москва, 1995. 18 с.

3. Мазуренко Е.А. Одиночество как френомен индивидуальной и социальной жизни : дис. ... канд. срилос. наук: 09.00.11. Архангельск, 2006. 164 с.

4. Майленова Ф.Г. Два лика одиночества. Человек. 2002. № 2. С. 129-135.

5. Молчанов В.И. Одиночество сознания и коммуникативность знака. Логос. 1997. № 9. С. 5-24.

6. Новицкая Л.Ф. Культура и возможность преодоления одиночества современного человека. Перифрерийность в культуре XX века: материалы
Всероссийской научно-практической конференции. Пермь, 2001. С. 217-230.

7. Пузанова Ж.В. Философрское одиночество и одиночество философра. Вестник Российского университета дружбы народов. Серия «Социология». 2003. № № 4-5. C. 47-58.

8. Пузанова Ж.В. Антропология одиночества. Социальная антропология на пороге XXI века. Москва, 1998. 355 с.

9. Романова Н.П. Социальный статус одиноких женщин в современном российском обществе: теоретико-методологический анализ : дис. ... докт. социолог. наук: 22.00.04. Улан-Удэ, 2006. 322 с.

10. Сіляєва В.І. Психологічне вивчення та корекція образу Я у самотніх жінок : дис. ... канд. психол. наук: 19.00.01. Сімферополь, 2004. 193 с.

11. Слободчиков И.М. Теоретико-экспериментальное исследование феномена одиночества личности : дис. ... докт. психол. наук: 19.00.01. Москва, 2006. $330 \mathrm{c}$.

12. Старовойтова Л.И. Одиночество: социальнофрилософский анализ : дис. ... канд. фрилос. наук: 09.00.11. Москва, 1995. 180 с.

13. Фаррахов А.Ф. Социальные фракторы, вызывающие чувство одиночества у молодых людей. Вестник Чувашского государственного педагогического университета имени И.Я. Яковлева. Серия «Гуманитарные и педагогические науки». 2013. № 3 (79). C. 168-173.

14. Шитова Н.В. Социально-психологические особенности одиноких женщин: дис. ... канд. психол. наук: 19.00.05. Воронеж, 2009. 189 с.

15. Familial Resemblance for Loneliness / M.A. Distel et al. Springer Link. 2010. № 40. P. 480-494. DOI: 10.1007/s10519-010-9341-5.

16. Dykstra P.A., Fokkema T. Social and Emotional Loneliness Among Divorced and Married Men and Women: Comparing the Deficit and Cognitive Perspectives. Basic and Applied Social Psychology. 2007. Vol. 29. DOI: 10.1080/01973530701330843. 